\title{
Public Health and Community Medicine
}

\section{Principal Component Analysis of Morbidity and Mortality among the United States Homeless Population: A Systematic Review and Meta-Analysis}

\author{
Albert Nguessan Ngo, $\mathrm{PhD}^{1,2^{*}}$ and David Joseph Turbow, $\mathrm{PhD}^{3^{*}}$ \\ ${ }^{1}$ Pharmaceutical Science, School of Pharmacy, American University of Health Sciences, USA \\ ${ }^{2}$ American University of Health Sciences Foundation, Signal Hill, CA, USA \\ ${ }^{3}$ Institutional Research and Assessment, American University of Health Sciences, USA
}

*Corresponding author: Albert Nguessan Ngo, Ph.D., Pharmaceutical Science, School of Pharmacy, American University of Health Sciences, P. 562-988-2278 Ext. 2055, 1600 E. Hill St., Signal Hill, CA 90755, USA, Fax: 562-988-1791;

David Turbow, Ph.D., Institutional Research and Assessment, American University of Health Sciences, P. 562-988-2278 ext. 2032, 1600 E. Hill St., Signal Hill, CA 90755, USA, Fax: 562-988-1791

\begin{abstract}
Background: Homelessness is a modern social and economic problem of major public health significance. In the United States of America (USA), several studies have identified different leading causes of morbidity and mortality among homeless populations.

For this systematic review, Principal Component Analysis (PCA), a multi-variate technique is applied to elucidate the strength of association of comorbidities and mortality among the U.S homeless population.

Methods: A search was conducted for published data for the 20-year period between 1/1/1998 and 12/31/2018. The keywords consisted of the terms: homeless, mortality, morbidity, United States, and health disparities. Data were drawn from cohort studies, observational studies and surveillance reports. Data were then extracted from eleven studies for meta-analysis using PCA.

Results: The first principal component analysis (PCA1) revealed a strong correlation between the co-morbidities of heart disease, cancer, diabetes, and psychoactive substance use. By contrast, PCA2 and PCA3 were strongly correlated to respiratory disease, and transportation-related injuries, respectively. Diseases correlated to PCA1, PCA2, and PCA3 were the major causes of mortality and morbidity of US homeless people with a prevalence of $53.88 \%$ (95\% Confidence Interval, Bartlett's test, Chi-square (X) $=228.941$, degree of freedom $(\mathrm{DF}=41.924)) ; 26.03 \%(X$ $=176.27, \mathrm{DF}=176.274)$ and $19.85 \%(\mathrm{X}=131.266, \mathrm{DF}=$ 131.266), respectively.
\end{abstract}

Conclusions: Based on the Principal Component Analysis (PCA), homeless people in the U.S. die mainly from heart disease, cancer, diabetes, and psychoactive substance use. Thus, there is a need to address health disparities and to further promote health education and intervention programs

\section{Keywords}

Homelessness, Mortality, Morbidity, United States, Health disparities, Principal component analysis

\section{Introduction}

According to the United States (U.S.) Department of Health and Human Services (HHS), a homeless person is defined in section $330(h)(5)(A)$ as "an individual who lacks housing (without regard to whether the individual is a member of a family), including an individual whose primary residence during the night is a supervised public or private facility (e.g., shelters) that provides temporary living accommodations, and an individual who is a resident in transitional housing" [1].

By early 1970, homelessness had been recognized as a national problem of major public health and economic significance in the U.S. [2]. However, at that time, morbidity and mortality rates associated with homelessness had not yet been formally documented $[3,4]$.

Citation: Ngo AN, Turbow DJ (2019) Principal Component Analysis of Morbidity and Mortality among the United States Homeless Population: A Systematic Review and Meta-Analysis. Int Arch Public Health Community Med 3:025. doi.org/10.23937/2643-4512/1710025

Accepted: August 07, 2019; Published: August 09, 2019

Copyright: (c) 2019 Ngo AN, et al. This is an open-access article distributed under the terms of the Creative Commons Attribution License, which permits unrestricted use, distribution, and reproduction in any medium, provided the original author and source are credited. 
Homelessness affects all types of people, irrespective of age and gender. There are currently an estimated 554,000 homeless people living in the U.S., representing $0.17 \%$ of the total U.S. population [5]. According to the National Health Service, the life expectancy of a homeless person is 30 years less than her/his counterpart who has a home. The life expectancy of a homeless person is less than 47.6-years on average. Thus, homelessness is strongly associated with early death [6]. While the total number of U.S. homeless declined over the period 2007 to 2015 , the homeless population increased in several major cities.

Many factors lead to homelessness: including lack of affordable housing [7-10], marriage separation, lawful eviction, post-traumatic stress disorder [11,12], foreclosure [13], accidental fire, and natural disasters such as hurricanes, and earthquakes. Other factors leading to homelessness include: poverty, lack of family support, substance abuse, mental impairment, and reduction in unemployment entitlements [14].

As of 2017, 28 million Americans are without health insurance and lack preventive health care [15]. One out of eight Americans is likely to become homeless and in poor health [16]. Homelessness itself is a contributing factor to human morbidity [17]. Poor health conditions and exposure to extreme weather conditions are cofactors that lessen the life expectancy of homeless people. For instance, many homeless perish during extreme hot weather events due to dehydration [15].

Homeless people are also prone to chronic diseases that are prevalent in the general population. In fact, the prevalence of diabetes and high blood pressure in the adult homeless population is identical to the general population [18]. According to a 2017 CDC report, 30.3 million (9.4\%) and 84.1 million Americans had diabetes and prediabetes [19]. Diabetes was the seventh foremost cause of death in the U.S. [19]. The prevalence of severe mental illness and substance abuse addiction is high in the homeless population leading to homelessness [20]. Many homeless people suffer from depression, anxiety, personality disorders, schizophrenia, heroin dependence, benzodiazepine dependence, alcohol dependency, bone fractures from assault, suicidal ideation and self-harm, asthma, gastrointestinal disease, tuberculosis, eczema, hepatitis C, hepatitis B and HIV/ AIDS [17]. Several efforts are devoted to homeless such as assertive community treatment in the rehabilitation of homeless persons with severe mental illness [21].

In this review article, we systematically elucidate the strength of association between comorbidities and mortality among the US homeless population based on principal component analysis (PCA), a multi-variate technique.

\section{Methods}

The systematic review was conducted following Pre- ferred Reporting Items for Systematic Reviews and Meta-analyses (PRISMA) guidelines [22].

Studies were selected for analysis based on the following inclusion criteria: the study must identify causes of mortality and morbidity among the United States homeless population. Only studies published from 1998-2018 were included for this analysis. As an exclusion criterion, studies focusing solely on one cause of disease (e.g., cancer) were excluded from this systematic and meta-analysis.

The literature search was conducted in Medline, PubMed, and Europe PubMed Central electronically. The following search terms were employed alone and in combination: causes, morbidity, mortality, homeless, United States, health disparities.

\section{Statistical Analysis}

\section{Principal component analysis and Bartlett's test}

The aim of Principal Component Analysis is to use an orthogonal transformation procedure to extract and present tabular data as a graph which best explains the variance [23]. In the present study, PCA was used to identify the leading causes of death in the U.S. homeless population based on previously published data from peer-reviewed and review articles related to mortality and morbidity among the U.S. homeless [24-26]. For this study, we drew upon the results of several previously published articles on the causes of mortality/morbidity of US homeless. PCA lends itself to meaningful analysis of health data by reducing the number of variables to a few, readily interpretable linear combinations of the original quantitative variables. Each linear combination of variables corresponds to a principal component $[27,28]$. The assumption is that each principal component is strongly intercorrelated with the original variable [28]. The correlation coefficient between the first principal component analysis (PCA1) is computed, followed by the second Principal component analysis (PCA2) etc. and the original quantitative variable for an efficient and rational interpretation of the data. The Pearson correlation coefficient is defined as follows:

$$
r=\frac{\operatorname{cov}(X, Y)}{S_{x} S_{y}}
$$

Where, $r$ is the correlation coefficient; $r$ varies from zero (no correlation) to one (perfect positive correlation) or one (perfect negative correlation); $\operatorname{cov}(X, Y)$ is the covariance of X and Y. $S_{x}$ and $S_{y}$ are the standards deviation of $X$ and $Y$, respectively. The eigenvalues are derived from the correlation matrix and provide useful information of the interpretation of the data. The correlation coefficient and the eigenvalues were computed using JMP software version 9.0.3 (SAS Institute, Cary, North Carolina, U.S.). A Bartlett's Test was used to determine whether there was homogeneity of variances among the different eigenvalues correlated to the 
principal component. For the purposes of our analysis, a p-value below 0.05 was considered a priori to warrant rejection of the null hypothesis.

\section{Results}

\section{Interpretation of the Principal Component Analysis}

We discovered 2016 articles with 800 identified as duplicates using Endnote software. After screening for article title and abstract, we then excluded an additional 1055 articles. Of the 163 articles assessed for eligibility, 126 were not related to US homeless, and 24 did not report causes of deaths. Finally, the remaining eleven articles were included in the qualitative and quantitative analyses. The study characteristics are shown in Table S1.
The Preferred Reporting Items for Systematic Review (PRISMA) flow diagram is shown in Figure 1. The selected studies for qualitative and meta-analysis are shown in Table 1.

A summary of the literature used for this systematic review is shown in Table S1.

\section{Statistical analysis for Mortality and morbidity in homeless population}

Figure 2A reveals the summary plot of the PCA1, PCA2 and PCA3 accounting for $53.8 \%, 26.41 \%$, and $19.55 \%$ of the variability of the sample respectively. The correlation coefficients between PCA1 and cancer, heart disease, psychoactive substance use, and diabetes
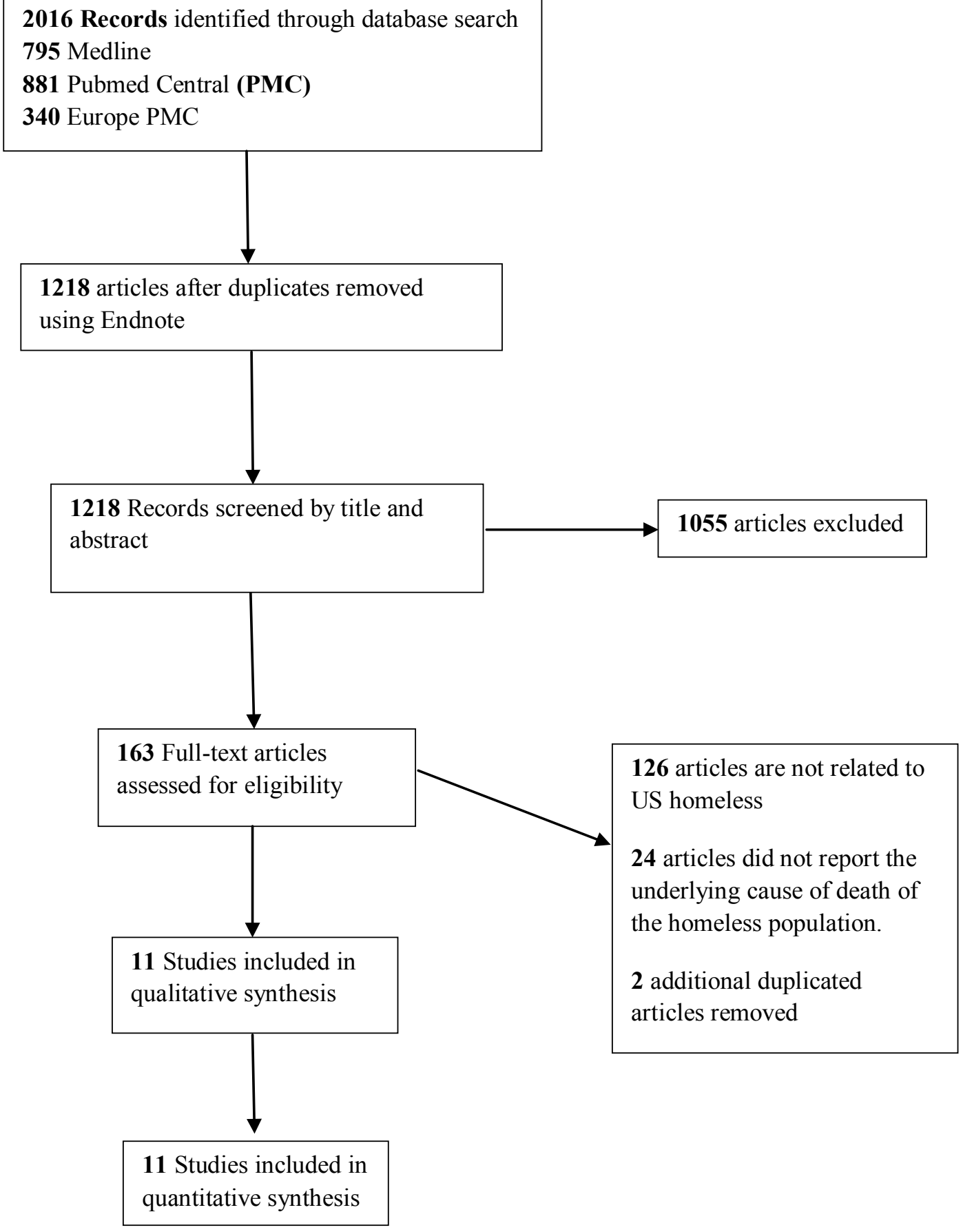

Figure 1: Prisma flow diagram of the systematic review and meta-analysis. 
Table 1: Underlying Causes of death observed in homeless population reported by several studies.

\begin{tabular}{|c|c|c|c|c|c|c|c|}
\hline Label & Cancer $^{\mathrm{a}}$ & $\begin{array}{l}\text { Heart } \\
\text { Disease }^{b}\end{array}$ & $\begin{array}{l}\text { Infectious } \\
\text { and Parasitic } \\
\text { Disease }^{c}\end{array}$ & $\begin{array}{l}\text { Respiratory } \\
\text { Disease }^{d}\end{array}$ & $\begin{array}{l}\text { Psychoactive } \\
\text { Substance }^{\mathrm{e}}\end{array}$ & $\begin{array}{l}\text { Injury } \\
\text { Transportations }\end{array}$ & $\begin{array}{l}\text { Diabetes and } \\
\text { metabolic } \\
\text { disease }^{g}\end{array}$ \\
\hline Roncarati, et al. [29] & 21 & 18 & 10 & 0 & 17 & 0 & 15 \\
\hline Bagget, et al. [26] & 206 & 203 & 76 & 0 & 219 & 0 & 114 \\
\hline Schinka, et al. [30] & 619 & 969 & 233 & 200 & 373 & 286 & 119 \\
\hline Pribish, et al. [31] & 0 & 10 & 0 & 50 & 32 & 59 & 25 \\
\hline Stephen, et al. [32] & 35 & 221 & 386 & 110 & 31 & 423 & 67 \\
\hline Henwood, et al. [33] & 9 & 21 & 12 & 3 & 23 & 49 & 1 \\
\hline Gambatese, et al. [34] & 0 & 23 & 0 & 0 & 27 & 7 & 0 \\
\hline Gawron, et al. [35] & 5848 & 23095 & 1136 & 220 & 37884 & 0 & 6351 \\
\hline Bharel, et al. [36] & 0 & 3220 & 1883 & 1712 & 3135 & 0 & 1191 \\
\hline Yamane, et al. [37] & 2 & 222 & 283 & 141 & 0 & 0 & 83 \\
\hline $\begin{array}{l}\text { Lebrun-Harris, et al. } \\
\text { [38] }\end{array}$ & 30 & 322 & 7 & 252 & 168 & 0 & 136 \\
\hline
\end{tabular}

a: Cancer incudes Trachea, bronchus and lung, liver and intrahepatic bile ducts, colon, rectum and anus, esophagus and pancreas cancer, neoplasm, melanoma, glaucoma; b: Heart disease includes cardiovascular system, hypertension, angina, myocardial infarction, congestive heart failure, arrhythmia, valvular heart disease, chronic venous insufficiency ischemic and non-ischemic heart diseases, coronary artery disease; ' : Infectious and parasitic disease include HIV/AIDS, parasitic disease, positive tuberculin, active tuberculosis, endocarditis, apoptotic ulcer disease, gastrointestinal disease, severe cirrhosis, Gonorrhea, hepatitis A hepatitis B, hepatitis C, Measles, Mumps, polio, Rubella, scarlet fever; ${ }^{d}$ : Respiratory disease includes pulmonary disease, asthma, whooping cough; : : Psychoactive substance use disorder includes alcohol use disorders, other substance use disorders, drug overdose; f: Injury transportation includes pedestrians injured in transport accident, falls, and drowning, fracture, dislocation, cerebral contusion, subdural hematoma, intracerebral hemorrhage, major chest injury, internal chest, abdomen or pelvis injury, frostbite, hypothermia or immersion foot; g: Diabetes and metabolic disease include, liver disease, diabetes.

Table 2: Principal component Analysis (PCA) on correlations matrix.

\begin{tabular}{|c|c|c|c|c|c|c|c|c|c|c|}
\hline & 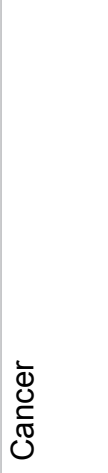 & 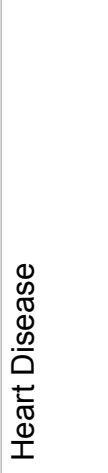 & 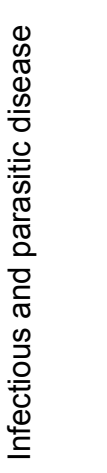 & 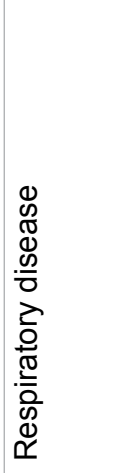 & 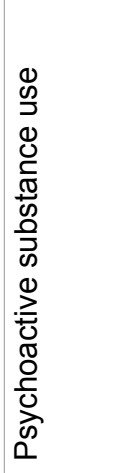 & 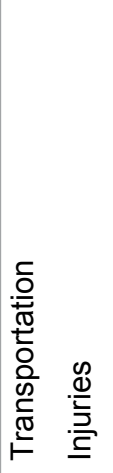 & 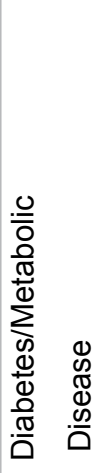 & ঠ্র & ষ্ণ & 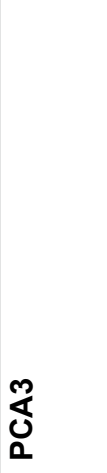 \\
\hline Cancer & 1.000 & 0.987 & 0.412 & -0.027 & 0.991 & -0.126 & 0.976 & 0.948 & -0.328 & 0.039 \\
\hline Heart Disease & 0.987 & 1.000 & 0.538 & 0.118 & 0.998 & -0.178 & 0.998 & 0.986 & -0.188 & -0.007 \\
\hline Infectious and parasitic disease & 0.412 & 0.538 & 1.000 & 0.874 & 0.118 & 0.998 & -0.178 & 0.998 & -0.188 & -0.007 \\
\hline Respiratory disease & -0.027 & 0.118 & 0.874 & 1.000 & 0.064 & -0.133 & 0.163 & 0.279 & 0.949 & -0.082 \\
\hline Psychoactive substance use & 0.991 & 0.998 & 0.492 & 0.064 & 1.000 & -0.186 & 0.995 & 0.976 & -0.241 & -0.017 \\
\hline Transportation Injuries & -0.126 & -0.178 & -0.082 & -0.133 & -0.186 & 1.000 & -0.200 & -0.215 & -0.036 & 0.985 \\
\hline Diabetes/Metabolic Disease & 0.976 & 0.998 & 0.575 & 0.163 & 0.995 & -0.200 & 1.000 & 0.993 & -0.142 & -0.028 \\
\hline
\end{tabular}

and metabolic disease were found to be greater than or equal to 0.948 , as shown in Table 2 . This suggests that homeless people died primarily from cancer, heart disease, psychoactive substance use, diabetes and metabolic disease. These health conditions reflect the major leading causes of death in the broader U.S. population. The PCA1 analysis also reveals that the original quantitative variables are inter-related and explain the preva- lence of commodities and mortality in the US homeless population. For instance, untreated health conditions such as diabetes can lead to heart-related events and conditions such as stroke and diabetic ketoacidosis $[39,40]$. Likewise, an addiction to psycho active substances can trigger the release of brain-derived neurotrophic factor, a brain protein associated with tumor growth [41].

The PCA 2 and PCA3 were found to be strongly related 
(A)

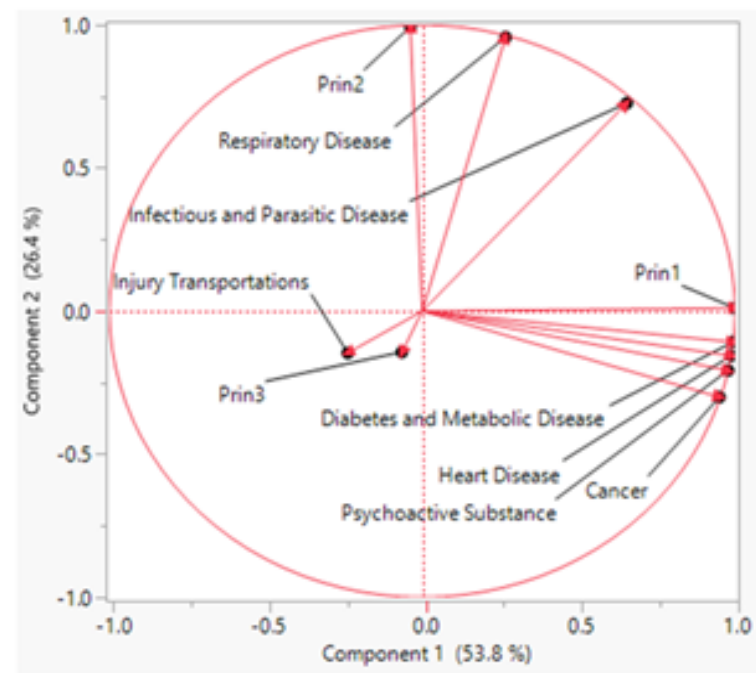

(B)

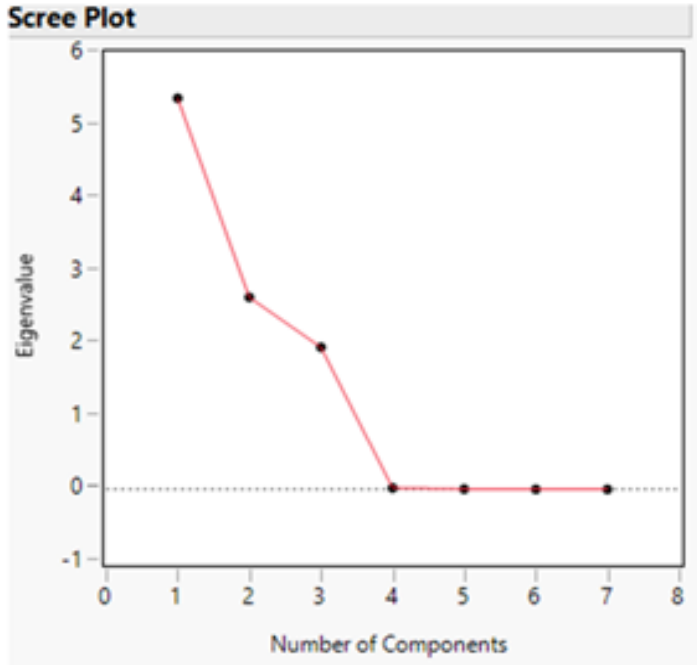

( C ) Eigenvalues

\begin{tabular}{|c|c|c|c|c|c|c|c|}
\hline Number & Eigenvalue & Percent & $\begin{array}{llll}20 & 40 & 60 & 80\end{array}$ & Cum Percent & ChiSquare & DF & Prob $>$ ChiSq \\
\hline 1 & 5.3882 & 53.882 & & 53.882 & 228.941 & 41.924 & $<, 0001^{*}$ \\
\hline 2 & 2.6034 & 26.034 & & 79.916 & 176.274 & 41.948 & $<.0001^{*}$ \\
\hline 3 & 1.9850 & 19.850 & & 99.766 & 131.266 & 36.642 & $<, 0001^{*}$ \\
\hline 4 & 0.0188 & 0.188 & & 99.954 & . & 30.369 & . \\
\hline 5 & 0.0044 & 0.044 & & 99.998 & . & 22.791 & . \\
\hline 6 & 0.0002 & 0.002 & & 100.000 & . & 16.597 & . \\
\hline 7 & 0.0000 & 0.000 & & 100.000 & . & 11.295 & . \\
\hline
\end{tabular}

\section{(D) Eigenvalues}

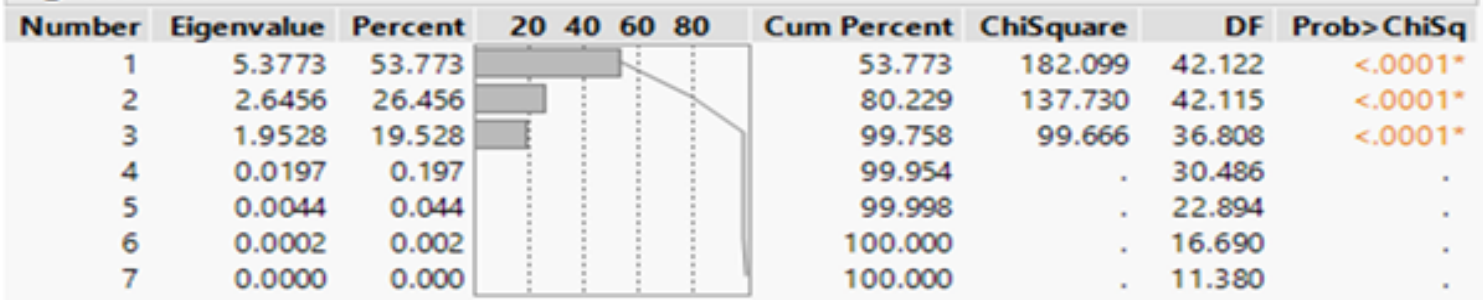

Figure 2: Principal component analysis summary plot. A) A scatterplot of the first two principal components; B) Scree plot displays a graph of the eigenvalue for each component. This scree plot helps in visualizing the dimensionality of the data space Loading Plot; C) Eigenvalue Pareto Plot: The percent and cumulative total percent of the variation accounted for by each principal component for the meta-analysis; D) sensitivity analysis using Eigenvalue Pareto Plot when study reporting less than 5 different disease are remove from the meta-analysis.

to respiratory disease and injuries from transportation. This suggests that respiratory disease and injury from transportation contribute significantly to the death of homeless people in U.S. with a prevalence of $26 \%$ and $19.95 \%$, respectively as shown in Figure 2C. PCA1, PCA2 and PCA3 were statistically significant and explain the major cause of deaths in U.S. population with a cumulative percentage $99.766 \%$ as shown in the scree plot Figure 2B. The other eigenvalues were found to be negligible. Thus, the scree plot suggests the use of three principal components is sufficient to yield meaningful analysis and interpretation of the data [42] (Table 2).

\section{Sensitivity Analysis}

A sensitivity analysis was conducted undertaken to determine the extent to which uncertainty in the PCA output could be allocated to different input sources thus corroborating the findings. In this second PCA analysis, studies reporting less than five causes of disease were removed from the meta-analysis. As shown in Figure 2C and Figure 2D, the PCA values were identical for PCA1 based on the sensitivity analysis. Likewise, PCA2 and PCA3 values for the meta-analysis ranges are [26.415-26.794] and [19.167-19.550] showing a narrow variation of the principal components. In addition, PCA1, PCA2 and PCA3 are still strongly correlated to the same original variable as shown in (Table S2).

\section{Discussion and Interventions}

As a method of analysis, PCA is advantageous in extracting the maximum of information explaining the primary cause of death of homeless people in the USA. 
As revealed by the PCA, untreated chronic diseases are the major contributing causes to early death among U.S. homeless people. Our analyses thus support previously published research on the topic [43]. For instance, Eyre, et al. reported that collectively cancer, heart disease, diabetes contribute to two-third of the deaths of US general population [44]. This corroborates our finding that in the U.S. homeless people die mainly from diseases correlated to PCA1 with a probability of 53.9\%. Unfortunately, many homeless people do not have access to preventive and affordable health care.

Health education programs such as Homeless Empowering Learning Program (HELP) may prove to be effective in reducing morbidity in U.S. homeless population. Those programs promote free educational training on both physical and mental preventive health care to homeless people [45]. Affordable and accessible preventive care for homeless people will be important programs needed to reduce the health disparities in homeless population. In this perspective, the U.S. Preventive Services Task Force (USPSF) approves several guidelines related to preventive care. Those preventive cares include but are not limited to disease screening, mental and behavioral screenings and safety screening and immunizations [39]. For instance, the creation of ambulatory care opportunities for homeless people and creation of health care facilities funded by the federal government or non-profit organization dedicated only to homeless population free of cost may be very beneficial to reduce the health disparities and improve the well-being of homeless people. A recent report of the Office of National Drug Control Policy revealed that $30 \%$ of people experiencing chronic homeless exhibits serious mental illness and substance used disorder and other chronic health disorder [21]. Interventions provided by the Substance Abuse and Mental Health Services Administration (SAMHSA) can be pivotal in the battle against mental illness. SAMHSA supports different behavioral health treatment and recovery-oriented services such as outreach, case management, treatment for mental and/or substance use disorders, peer support services, Medicaid and employment readiness services [46].

Here we note the limitations of our systematic review. First, the data inputs are generalized by major types of diseases and injuries types and are pooled for specific cities. This represents an important opportunity to conduct extensive research on health education, promotion and prevention program among U.S. homeless populations. Indeed, those health programs such as homeless empowering learning programs can be beneficial for homeless in many health-related categories: health fostering behavior change, health knowledge, health literacy physical markers of health risk factors, actual physical changes in health and improved food security, and health assessment [47].

\section{Conclusions}

Homelessness is a societal, economic and moral problem in U.S. The results of this review with PCA reveal that the major causes of death in homeless population mirror leading causes of death in U.S. general population: Heart disease, cancer, and diabetes/metabolic disease.

Given this stronger understanding of the proximate causes of homelessness, policy levers should be implemented accordingly. Much remains to be done to reduce the health disparities and higher rate of morbidity and mortality in homeless population. Health education and interventions programs such as Homeless Empowering Learning Program (HELP) are indeed very crucial to improve the well-being and life expectancy of USA homeless people. This systematic review sheds new light on an issue of major public health significance and points to the need for leveraged research on improving the health status of homeless people.

\section{Acknowledgments and Disclosure}

This work was supported by the American University of Health Sciences Foundation, Signal Hill, CA, USA, grant\# IG020719C

\section{Authors Contributions}

ANN designed and analyzed the data and drafted the first manuscript. DT generated additional idea and helped and validated the interpretation of the Principal Component Analysis by ANN. All authors edited the manuscript, reviewed and approved the final version, and agreed to be accountable for all aspects of the work.

The views expressed in this article are those of the authors and do not necessarily represent the views of the American university of Health Sciences.

\section{Human Participant Protection}

Institutional review board approval was not required because the study scrutinized and synthesized published data only which informed consent has already been obtained by different investigators.

\section{References}

1. National health care for the homeless Council.

2. O'Connell JJ, Oppenheimer SC, Judge CM, Taube RL, Blanchfield BB, et al. (2010) The Boston health care for the Homeless program: A public health framework. Am J Public Health 100: 1400-1408.

3. Kusmer K (2002) Down and Out, On the Road: The Homeless in American History. Oxford University Press, New York, NY.

4. Howard K, Koh JJOC (2016) Improving Health Care for Homeless People. JAMA 316: 2586-2587.

5. Meghan Henry, Anna Mahathey, Tyler Morril, Anna Robinson, Azim Shivji, et al. (2018) The 2018 Annual Homeless Assessment Report (AHAR) to congress. The Department of Housing and Urban development/office of community 
planning and development.

6. Cha O (2013) Health of the homeless. Bull Acad Natl Med 197: 277-289.

7. AMC III (2016) Homelessness and the Crisis of Affordable Housing: The Abandonment of a Federal Affordable Housing Policy. Journal of Affordable Housing, 25.

8. Jagielski T, Minias A, Van Ingen J, Rastogi N, Brzostek A, et al. (2016) Methodological and Clinical Aspects of the Molecular Epidemiology of Mycobacterium tuberculosis and Other Mycobacteria. Clin Microbiol Rev 29: 239-290.

9. Krugman (2017) Why is housing so expensive?

10. Wright JD, Rubin BA (2010) Is Homelessness a Housing problem? Housign Policy Debate 2: 937-956.

11. North CS, Smith EM (1992) Posttraumatic stress disorder among homeless men and women. Hosp Community Psychiatry 43: 1010-1016.

12. Morrison A, Mcllduff B (2007) Re-emergence of symptoms of posttraumatic stress disorder in a homeless woman. Psychiatry (Edgmont) 4: 60-64.

13. Ochi NG (2010) The California Tenant Stability Act: A Solution for renters affected by the foreclosure crisis. Geargetwon Jouranl on Poverty Law\& Policy, 17.

14. Publishing AP (2013) Diagnostic and Statistical Manual of Mental Disorders. American Psychiatric Association, 271280.

15. Greene J (2011) Helping the Homeless During Extreme Hot Weather Emergencies. Boston Public Health Commission.

16. CDC (2017) National Homeless Person's Memorial Day.

17. Hewett N, Hiley A, Gray J (2011) Morbidity trends in the population of a specialised homeless primary care service. Br J Gen Pract 61: 200-202.

18. Bernstein RS, Meurer LN, Plumb EJ, Jackson JL (2015) Diabetes and hypertension prevalence in homeless adults in the United States: A systematic review and metaanalysis. Am J Public Health 105: e46-e60.

19. CDC (2017) National Diabetes Statistics Report, 2017 Estimates of Diabetes and Its Burden in the United States.

20. Editors PLM (2008) Homelessness is not just a housing problem. PLoS Med 5: e3.

21. Coldwell CM, Bender WS (2007) The effectiveness of assertive community treatment for homeless populations with severe mental illness: A meta-analysis. Am J Psychiatry 164: 393-399.

22. Fang F, Zhang Y, Tang J, Lunsford LD, Li T, et al. (2019) Association of Corticosteroid Treatment with Outcomes in Adult Patients with Sepsis: A Systematic Review and Metaanalysis. JAMA Intern Med 179: 213-223.

23. Daultrey S (1976) Principal Component Analysis.

24. Baggett TP, Liauw SS, Hwang SW (2018) Cardiovascular Disease and Homelessness. J Am Coll Cardiol 71: 25852597.

25. Slockers MT, Nusselder WJ, Rietjens J, Van Beeck EF (2018) Homeless adults' most frequent cause of death is suicide or murder. Ned Tijdschr Geneeskd 162: D2626.

26. Baggett TP, Hwang SW, O'Connell JJ, Porneala BC, Stringfellow EJ, et al. (2013) Mortality among homeless adults in Boston: Shifts in causes of death over a 15-year period. JAMA Intern Med 173: 189-195.
27. Yao F, Coquery J, Le Cao KA (2012) Independent Principal Component Analysis for biologically meaningful dimension reduction of large biological data sets. BMC Bioinformatics 13: 24.

28. Lever J, Krzywinski M, Altman N (2017) Principal component analysis. Nature Methods 14: 641.

29. Roncarati JS, Baggett TP, O'Connell JJ, Hwang SW, Cook EF, et al. (2018) Mortality among unsheltered homeless adults in Boston, Massachusetts, 2000-2009. JAMA Intern Med 178: 1242-1248.

30. Schinka JA, Leventhal KC, Lapcevic WA, Casey R (2018) Mortality and cause of death in younger homeless veterans. Public Health Rep 133: 177-181.

31. Pribish A, Khalil N, Mhaskar R, Woodard L, Mirza AS (2019) Chronic Disease Burden of the Homeless: A descriptive study of Student-Run free clinics in Tampa, Florida. J Community Health 44: 249-255.

32. Stephen W Hwang, Joan M Lebow, Michael F Bierer, Jmaes J O'Connell, John Orav, et al. (1998) Risk Factors for Death in Homeless adults in Boston. Arch Intern Med 158: $1454-1460$.

33. Henwood BF, Byrne T, Scriber B (2015) Examining mortality among formerly homeless adults enrolled in Housing First: An observational study. BMC Public Health 15: 1209.

34. Gambatese M, Marder D, Begier E, Gutkovich A, Mos R, et al. (2013) Programmatic impact of 5 years of mortality surveillance of New York City homeless populations. Am J Public Health 103: S193-198.

35. Gawron LM, Redd A, Suo Y, Pettey W, Turok DK, et al. (2017) Long-acting reversible contraception among homeless women veterans with chronic health conditions: A retrospective cohort study. Med Care 55: S111-S120.

36. Bharel M, Lin WC, Zhang J, O'Connell E, Taube R, et al. (2013) Health care utilization patterns of homeless individuals in Boston: preparing for Medicaid expansion under the Affordable Care Act. Am J Public Health 103: S311-317.

37. Yamane DP, Oeser SG, Omori J (2010) Health disparities in the Native Hawaiian homeless. Hawaii Med J 69: 35-41.

38. Lebrun-Harris LA, Baggett TP, Jenkins DM, Sripipatana A, Sharma R, et al. (2013) Health status and health care experiences among homeless patients in federally supported health centers: findings from the 2009 patient survey. Health Serv Res 48: 992-1017.

39. J. KKaP (2017) Preventive care for people experiencing homelessness Part I of II in a series on preventive care. A Publication of the HCH Clinicians' Network, 21.

40. Papatheodorou K, Papanas N, Banach M, Papazoglou D, Edmonds M (2016) Complications of Diabetes 2016. J Diabetes Res 2016: 6989453.

41. Sarabi M, Perraud A, Mazouffre C, Nouaille M, Jauberteau $\mathrm{MO}$, et al. (2017) Psychoactive drugs influence brain-derived neurotrophic factor and neurotrophin 4/5 levels in the serum of colorectal cancer patients. Biomed Rep 6: 89-94.

42. Smith BD, Yartel AK (2014) Comparison of Hepatitis C virus testing strategies: Birth cohort versus elevated alanine aminotransferase levels. Am J Prev Med 47: 233-241.

43. Valvassori $P$ (2014) Chronic Disease management in the Homeless. Health Care Center for the Homeless.

44. Eyre H, Kahn R, Robertson RM, Clark NG, Doyle C, et al. (2004) Preventing cancer, cardiovascular disease, and 
diabetes: A common agenda for the American Cancer Society, the American Diabetes Association, and the American Heart Association. Stroke 35: 1999-2010.

45. Ryti NR, Guo Y, Jaakkola JJ (2016) Global association of cold spells and adverse health effects: A systematic review and meta-analysis. Environ Health Perspect 124: 12-22.
46. Blazer DG, Wu LT (2009) The epidemiology of at-risk and binge drinking among middle-aged and elderly community adults: National survey on drug use and health. Am J Psychiatry 166: 1162-1169.

47. Wiggins $N$ (2012) Popular education for health promotion and community empowerment: a review of the literature. Health Promot Int 27: 356-371. 
Table S1: Summarizing literature uses in the systematic review and meta-analysis.

\begin{tabular}{|c|c|c|c|c|c|c|c|}
\hline $\begin{array}{l}\text { Study and } \\
\text { publication } \\
\text { date }\end{array}$ & Location & $\begin{array}{l}\text { Study } \\
\text { characteristic }\end{array}$ & $\begin{array}{l}\text { Sampling } \\
\text { Method }\end{array}$ & $\begin{array}{l}\text { Diagnostic } \\
\text { Method }\end{array}$ & $\begin{array}{l}\text { Special } \\
\text { population }\end{array}$ & $\begin{array}{l}\text { No. of } \\
\text { Participants }\end{array}$ & $\begin{array}{l}\text { Year of } \\
\text { study }\end{array}$ \\
\hline $\begin{array}{l}\text { Roncarati, et } \\
\text { al. [29] }\end{array}$ & Boston, MA & $\begin{array}{l}\text { Prospective } \\
\text { Cohort Study }\end{array}$ & $\begin{array}{l}\text { Homeless } \\
\text { Program, Street } \\
\text { team }\end{array}$ & $\begin{array}{l}\text { Medical records, } \\
\text { clinical, national } \\
\text { death index }\end{array}$ & $\begin{array}{l}\text { Unsheltered } \\
\text { homeless }\end{array}$ & 445 & $\begin{array}{l}2000- \\
2009\end{array}$ \\
\hline $\begin{array}{l}\text { Bagget, et al. } \\
\text { [26] }\end{array}$ & Boston, MA & Cohort study & $\begin{array}{l}\text { Boston } \\
\text { Healthcare }\end{array}$ & $\begin{array}{l}\text { Massachusetts } \\
\text { deaths } \\
\text { occurrence file }\end{array}$ & Unspecified & 28,033 & $\begin{array}{l}2003- \\
2008\end{array}$ \\
\hline $\begin{array}{l}\text { Schinka, et } \\
\text { al. [30] }\end{array}$ & $\begin{array}{l}\text { Tampa, } \\
\text { Florida }\end{array}$ & Cohort Study & $\begin{array}{l}\text { Veterans affairs } \\
\text { records }\end{array}$ & $\begin{array}{l}\text { National Death } \\
\text { index record }\end{array}$ & $\begin{array}{l}\text { Homeless } \\
\text { veterans }\end{array}$ & 23,898 & $\begin{array}{l}2000- \\
2011\end{array}$ \\
\hline $\begin{array}{l}\text { Pribish, et al. } \\
\text { [31] }\end{array}$ & $\begin{array}{l}\text { Tampa, } \\
\text { Florida }\end{array}$ & $\begin{array}{l}\text { Retrospective } \\
\text { Cohort Study }\end{array}$ & $\begin{array}{l}\text { Tampa Bay } \\
\text { Street medicine }\end{array}$ & clinic & $\begin{array}{l}\text { Homeless in } \\
\text { Tampa }\end{array}$ & 183 & $\begin{array}{l}2015- \\
2016\end{array}$ \\
\hline $\begin{array}{l}\text { Stephen, et } \\
\text { al. [32] }\end{array}$ & Boston, MA & $\begin{array}{l}\text { Case Control } \\
\text { Study }\end{array}$ & $\begin{array}{l}\text { Boston } \\
\text { homeless } \\
\text { Healthcare }\end{array}$ & $\begin{array}{l}\text { Medical } \\
\text { Records }\end{array}$ & $\begin{array}{l}\text { Homeless in } \\
\text { Boston }\end{array}$ & 558 & $\begin{array}{l}1993- \\
1998\end{array}$ \\
\hline $\begin{array}{l}\text { Henwood, et } \\
\text { al. [33] }\end{array}$ & $\begin{array}{l}\text { Philadelphia., } \\
\text { PA }\end{array}$ & $\begin{array}{l}\text { Observational } \\
\text { Study }\end{array}$ & $\begin{array}{l}\text { Housing First } \\
\text { (HF) programs }\end{array}$ & HF staff records & $\begin{array}{l}\text { Sheltered } \\
\text { Homeless }\end{array}$ & 292 & $\begin{array}{l}2008- \\
2013\end{array}$ \\
\hline $\begin{array}{l}\text { Gambatese, } \\
\text { et al. [34] }\end{array}$ & $\begin{array}{l}\text { New York City, } \\
\text { NJ }\end{array}$ & $\begin{array}{l}\text { Retrospective } \\
\text { cohort study }\end{array}$ & $\begin{array}{l}\text { Homeless } \\
\text { surveillance } \\
\text { system }\end{array}$ & $\begin{array}{l}\text { Medical } \\
\text { examiner }\end{array}$ & $\begin{array}{l}\text { Sheltered and } \\
\text { unsheltered } \\
\text { homeless }\end{array}$ & 3262 & $\begin{array}{l}2005- \\
2010\end{array}$ \\
\hline $\begin{array}{l}\text { Gawron, et } \\
\text { al. [35] }\end{array}$ & US VHA & $\begin{array}{l}\text { Retrospective } \\
\text { cohort Study }\end{array}$ & $\begin{array}{l}\text { Veterans' } \\
\text { Healthcare } \\
\text { Administration } \\
\text { (VHA) }\end{array}$ & VHA Care & $\begin{array}{l}\text { Homeless } \\
\text { Veteran Women }\end{array}$ & 41747 & $\begin{array}{l}2002- \\
2015\end{array}$ \\
\hline $\begin{array}{l}\text { Bharel, et al. } \\
{[36]}\end{array}$ & Boston, MA & Cohort Study & $\begin{array}{l}\text { Boston Health } \\
\text { Care for the } \\
\text { Homeless } \\
\text { Program } \\
(\mathrm{BHCHP})\end{array}$ & BHCHP care & Boston homeless & 6494 & 2010 \\
\hline $\begin{array}{l}\text { Yamane, et } \\
\text { al. [37] }\end{array}$ & Hawaii & $\begin{array}{l}\text { Retrospective } \\
\text { cohort Study }\end{array}$ & $\begin{array}{l}\text { Hawaii's } \\
\text { Homelesss } \\
\text { Outreach } \\
\text { and Medical } \\
\text { Education } \\
\text { (H.O.M.E) }\end{array}$ & $\begin{array}{l}\text { Record of } \\
\text { H.O.M.E. }\end{array}$ & Hawaii's & 1182 & 2009 \\
\hline
\end{tabular}

Table S2: Principal component Analysis (PCA) on correlations matrix for sensitivity analysis.

\begin{tabular}{|c|c|c|c|c|c|c|c|c|c|c|}
\hline & 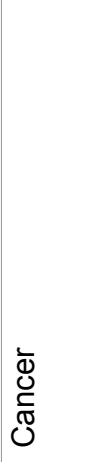 & 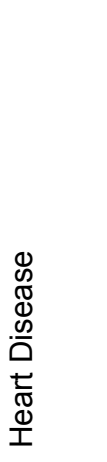 & 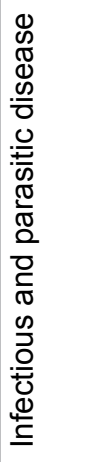 & 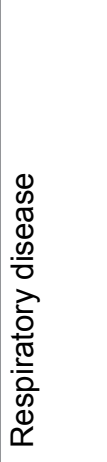 & 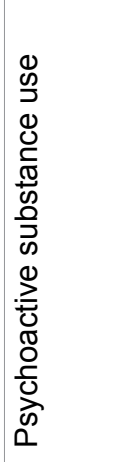 & 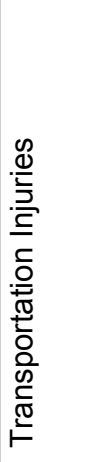 & 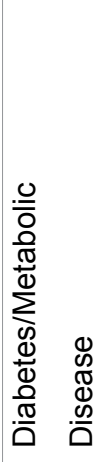 & ষ্র & ঠั & ষ্ঠু \\
\hline Cancer & 1.000 & 0.986 & 0.399 & -0.047 & 0.991 & -0.147 & 0.976 & 0.947 & -0.348 & 0.018 \\
\hline Heart Disease & 0.986 & 1.000 & 0.528 & 0.099 & 0.998 & -0.201 & 0.998 & 0.986 & -0.207 & -0.030 \\
\hline Infectious and parasitic disease & 0.399 & 0.528 & 1.000 & 0.871 & 0.483 & -0.118 & 0.565 & 0.658 & 0.712 & 0.002 \\
\hline Respiratory disease & -0.047 & 0.099 & 0.871 & 1.000 & 0.046 & -0.163 & 0.146 & 0.261 & 0.948 & -0.117 \\
\hline Psychoactive substance use & 0.991 & 0.998 & 0.483 & 0.047 & 1.000 & -0.207 & 1.000 & -0.225 & -0.243 & -0.057 \\
\hline Transportation Injuries & -0.147 & -0.201 & -0.118 & -0.163 & -0.207 & 1.000 & -0.225 & -0.243 & -0.057 & 0.985 \\
\hline Diabetes/Metabolic Disease & 0.976 & 0.998 & 0.565 & 0.146 & 0.995 & -0.225 & 1.000 & 0.993 & -0.161 & -0.054 \\
\hline
\end{tabular}

